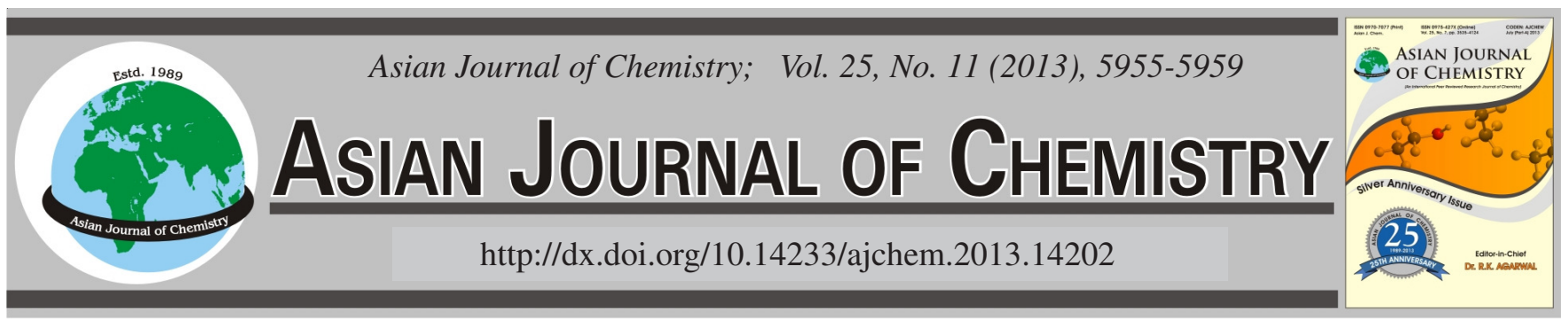

\title{
Optimization of Extraction and Dyeing Parameters for Natural Dyeing of Cotton Fabric Using Marigold (Tagetes erecta)
}

\section{Assad Farooq ${ }^{1, *}$, Shaukat Ali ${ }^{2}$, Naheed Abbas $^{3}$, Naila Zahoor $^{3}$ and Muhammad Azeem Ashraf ${ }^{1, *}$}

\author{
${ }^{1}$ Department of Fibre and Textile Technology, University of Agriculture, Faisalabad, Pakistan \\ ${ }^{2}$ Department of Chemistry \& Biochemistry, University of Agriculture, Faisalabad, Pakistan \\ ${ }^{3}$ Institute of Rural Home Economics, University of Agriculture, Faisalabad, Pakistan \\ *Corresponding author: Fax: +92 41 9201267; Tel: +92 3006628872; E-mail: assadfarooq@googlemail.com
}

\begin{abstract}
The present work involves the optimization of extraction and dyeing recipes to standardize the procedure for natural dye obtained from the petals of marigold (Tagetes erecta). The resultant dye obtained at optimized extraction conditions was applied on cotton fabric to study the effect of temperature, time, material to liquid ratio (M:L), salt concentration and mordanting. Colorimetric data and colour fastnesses were studied for evaluation of optimum extraction and dyeing conditions. It was observed that extraction and dyeing parameters have significant effect on colour characteristics of dyed cotton fabric. The optimized extraction conditions were; M:L ratio 1:20, extraction time $90 \mathrm{~min}$ and temperature $100^{\circ} \mathrm{C}$ while optimized dyeing parameters were; M:L ratio $1: 30$, dyeing time $1 \mathrm{~h}$ and temperature $90{ }^{\circ} \mathrm{C}$ and salt concentration $60 \mathrm{~g} / \mathrm{L}$ of sodium sulphate. Better light and washing fastness were obtained in case of post mordanting with ferrous sulphate.
\end{abstract}

Key Words: Natural dyes, Marigold, Cotton, Environment friendly dyeing, Mordant.

\section{INTRODUCTION}

Recently a renaissance of interest is happened in the usage of natural dyes in textile coloration. This is in the result of the strict ecological standards forced by many countries as a consequence of poisonous and allergic reactions related to the use of synthetic dyes. A prevalent attention has emerged in the dyeing of fabric fibers by the means of natural colorants, on description of their high compatibility with surroundings. They have softer colour shades, unaffectedness qualities and lesser toxicity. These dyes are also uncontaminated, antiallergic and deodorizing that are sufficient for balancing natural shades or just the originality ${ }^{1-3}$.

Natural dyes are obtained from flowers, berries, leaves, trees, shrubs, minerals and insects. These dyes have been used for centuries to develop colours for yarns, fabrics, leather and foods, etc. Natural dyes can provide delicate and soft colours through to the brightest colour to the yarns and fabrics. Ancient dyeing methods integrated sticking plants to fabric or rubbing crushed pigments into cloth. The methods became more stylish with time and techniques using natural dyes from crushed fruits, berries and other plants, which were boiled into the fabric, were developed. The natural dye extraction methods and dyeing methods described by traditional dyers are incomplete. Therefore, there is a requirement to produce and standardize newer techniques for the extraction and application of natural dyes ${ }^{4}$.

Natural dyes have little affinity towards cotton so some chemicals such as mordants are used for improving fastness properties of natural dyes on fibre. Natural dyes applied without mordant have poor fastness properties. A mordant is an element which aids the chemical reaction that takes place between the dye and the fiber so that the dye is absorbed. Metallic salts are usually used as mordants in most dyeing process. The metal ions act as acceptors to electron donors to form co-ordinate bonds with dye molecule, which is insoluble in water ${ }^{5}$.

Many varieties of Marigolds have been cultivated all over the world but two of them are Tagetes erecta and Tagetes patula are most important. Marigold plants are chubby and branching and can grow up to $60 \mathrm{~cm}$ tall ${ }^{6,7}$. Marigold flowers contain compounds called carotenoids. Lutein $\left(\mathrm{C}_{40} \mathrm{H}_{56} \mathrm{O}_{2}\right)$ is a natural dye that belongs to the carotenoid family ${ }^{8}$. Lutein and its isomer zeaxanthin are also known as oxycarotenoids or xanthophylls. These xanthophylls are the basic element in the marigold flowers and present in high concentration than other plants. The xanthophylls because of their yellow to orangered coloration and natural occurrence in human foods can be 
used as a food colorant. Therefore there exist a high demand for the significantly pure xanthophylls that can be used as a food colorant and a nutrient supplement. Marigold extract also finds application in coloring foods like edible oils, mustard and other salad dressings, cakes, ice cream, yogurt and dairy products.

In this research work efforts are made to device industrial technologies of natural dyes for optimum process parameters to standardize the procedure.

\section{EXPERIMENTAL}

Marigold (Tagetes eracta) flowers were collected from the botanical garden of University of Agriculture, Faisalabad Pakistan. The petals were separated, washed out thoroughly and dried in the sun. Then dried petals were grounded to powder form. This marigold flower powder was used in all the succeeding experiments to extract colorant. $100 \%$ bleached cotton fabric purchased from local textile industry was used for dyeing. Analytical grade reagents sodium sulphate $\left(\mathrm{Na}_{2} \mathrm{SO}_{4}\right)$, alum $\mathrm{KAl}\left(\mathrm{SO}_{4}\right)_{2} \cdot 12 \mathrm{H}_{2} \mathrm{O}$ and ferrous sulphate $\left(\mathrm{FeSO}_{4}\right)$ were used for dyeing experiments. All dyeing experiments were carried out in lab scale HT dyeing machine (Advance System Logic Pakistan) by exhaust method. SDL Atlas Crock meter was used for testing rubbing fastness while Launder-o-meter (SDL Atlas, USA) was used for washing fastness tests. Atlas Ci3000 Weather-Ometer was used for light fastness testing.

Optimization of extraction conditions: Different experiments were carried out to optimize extraction parameters such as time, temperature and M:L ratio. Extraction was carried out by using water as solvent. Marigold dye extraction was done in soxhlet apparatus at room temperature, 50, 70 and $100{ }^{\circ} \mathrm{C}$ for temperature optimization. For optimization of extraction time and M:L ratio, dye extraction was carried out for $30,60,90$ and $120 \mathrm{~min}$ using M:L ratio 1:10, 1:20 and $1: 30$ at optimized temperature of $100{ }^{\circ} \mathrm{C}$. Then all extracts were used to dye $10 \mathrm{~g}$ of bleached $100 \%$ cotton fabric by exhaust method in lab scale HT dyeing machine using M:L ratio of $1: 30$ for $1 \mathrm{~h}$ at $90^{\circ} \mathrm{C}$ with $60 \mathrm{~g} / \mathrm{L}$ salt.

Optimization of dyeing conditions: After extraction, effects of dyeing parameters such as temperature, dyeing time, liquor ratio salt concentration and mordanting were noted for process optimization. Cotton fabrics were dyed by exhaust method in lab scale HT dyeing machine using filtered extract at $40,60,80$ and $90{ }^{\circ} \mathrm{C}$ for $1 \mathrm{~h}$ for temperature optimization. To study the effect of M:L ratio dyeing was done using 1:10, $1: 20$ and $1: 30$ material to liquid ratios at $90{ }^{\circ} \mathrm{C}$. In order to observe the effect of dyeing time dyeing was carried out for 30, 60 and $90 \mathrm{~min}$. Three levels of salt (sodium sulphate) 20, 40 and $60 \mathrm{~g} / \mathrm{L}$ were used to investigate the effect of salt on dyeing.

Mordanting: Pre mordanting with alum and post mordanting with ferrous sulphate $\left(\mathrm{FeSO}_{4}\right)$ was carried out using 5 and $10 \%$ (o.w.f) concentration levels of mordants to observe the effect of mordant at 60 and $90{ }^{\circ} \mathrm{C}$.

Colour measurements: Colorimetric values $\mathrm{L}, \mathrm{a}^{*}, \mathrm{~b}^{*}$, $\mathrm{c}^{*}, \mathrm{~h}^{*}$ and K/S of dyed fabrics were measured according to CIE system using spectrophotometer data colour spectraflash SF-600.
Evaluation of colour fastness properties: Colour fastness to washing, rubbing and light tests were performed using ISO standards test methods after dyeing for quality assurance purpose.

\section{RESULTS AND DISCUSSION}

\section{Optimization of extraction conditions}

Effect of temperature: From the colour strength values presented in the Table- 1 it is clear that colour strength values increase with rise in temperature from room temperature to boiling temperature $\left(100^{\circ} \mathrm{C}\right)$. With the increase in temperature, cell wall ruptures and more dye component comes out into the extract and dissolves. As more dye is extracted it gives more colour strength value. At high temperature, solubility of dye is increased so it comes more in filtrate and less in residue. Hence increased colour strength was observed at boiling temperature (Fig. 1). There is general trend of rise in colour strength value with increasing temperature for extraction.

\begin{tabular}{|c|c|c|c|c|c|c|}
\hline \multicolumn{7}{|c|}{$\begin{array}{c}\text { TABLE-1 } \\
\text { EFFECT OF TEMPERATURE ON COLORIMETRIC } \\
\text { VALUES FOR EXTRACTION CONDITIONS }\end{array}$} \\
\hline Temp. $\left({ }^{\circ} \mathrm{C}\right)$ & $\mathrm{K} / \mathrm{S}$ & $\mathrm{L}^{*}$ & $a^{*}$ & $b^{*}$ & $\mathrm{c}^{*}$ & $\mathrm{~h}$ \\
\hline Room temp. & 0.96 & 60.02 & -2.26 & 25.88 & 25.90 & 94.40 \\
\hline 50 & 1.52 & 60.00 & -2.27 & 25.87 & 26.91 & 95.13 \\
\hline 70 & 1.96 & 60.04 & -2.25 & 25.90 & 26.95 & 95.11 \\
\hline 100 & 2.86 & 60.00 & -2.27 & 25.90 & 26.00 & 95.01 \\
\hline
\end{tabular}

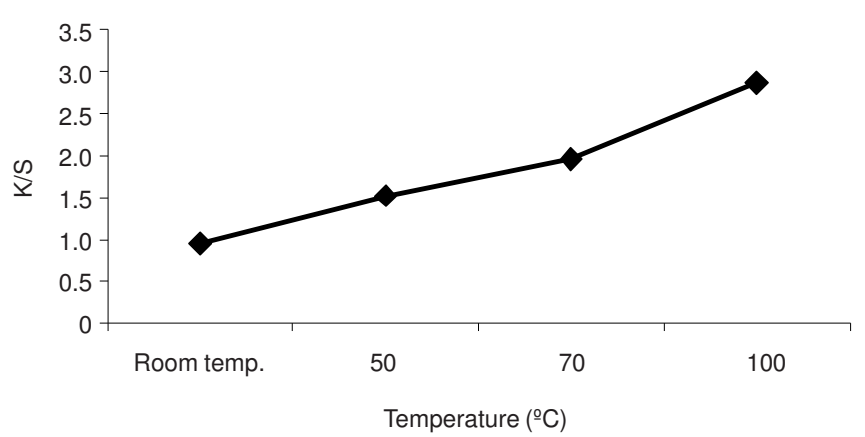

Fig. 1. Effect of extraction temperature on colour strength

Effect of M:L ratio: Table-2 showed that with increasing M:L ratio from 1:10 to 1:20 colour strength value increases and then further increase in M:L ratio decrease the colour strength. When the M:L ratio is less, the dye molecules are congested, they collide with each other which increases the affinity of dye molecules for each other and decrease their affinity for the fabric, hence decrease the colour strength (Fig. 2).

TABLE-2

EFFECT OF M:L RATIO AT OPTIMIZED TEMPERATURE FOR EXTRACTION CONDITIONS

\begin{tabular}{ccccccc} 
M:L ratio & $\mathrm{K} / \mathrm{S}$ & $\mathrm{L}^{*}$ & $\mathrm{a}^{*}$ & $\mathrm{~b}^{*}$ & $\mathrm{c}^{*}$ & $\mathrm{~h}$ \\
\hline $1: 10$ & 1.91 & 60.02 & -2.26 & 25.88 & 25.90 & 94.63 \\
$1: 20$ & 2.87 & 60.00 & -2.26 & 25.90 & 26.00 & 95.02 \\
$1: 30$ & 2.24 & 60.00 & -2.27 & 25.87 & 26.91 & 95.13 \\
\hline
\end{tabular}

Effect of extraction time: The colour strength increases with increase of extraction time (Table-3). The increase in colour 


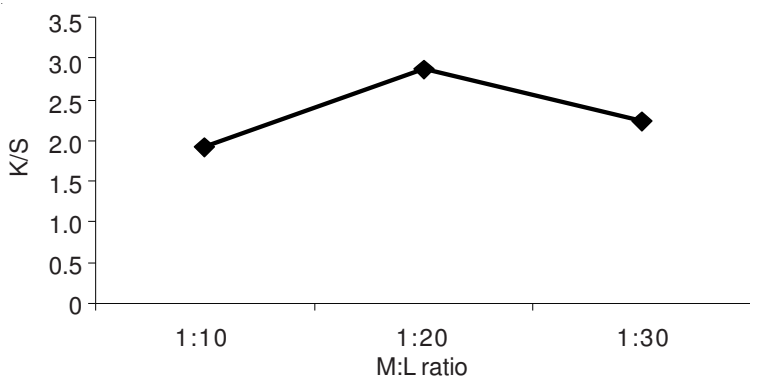

Fig. 2. Effect of M:L ratio on colour strength

\begin{tabular}{|c|c|c|c|c|c|c|}
\hline \multicolumn{7}{|c|}{$\begin{array}{c}\text { TABLE-3 } \\
\text { EFFECT OF EXTRACTION TIME AT OPTIMIZED } \\
\text { TEMPERATURE FOR EXTRACTION CONDITIONS }\end{array}$} \\
\hline $\begin{array}{l}\text { Extraction } \\
\text { time (min) }\end{array}$ & $\mathrm{K} / \mathrm{S}$ & $\mathrm{L}^{*}$ & $\mathrm{a}^{*}$ & $b^{*}$ & $\mathrm{c}^{*}$ & $\mathrm{~h}$ \\
\hline 30 & 1.02 & 59.25 & -2.01 & 25.63 & 24.28 & 95.11 \\
\hline 60 & 1.95 & 59.53 & -2.35 & 25.58 & 25.13 & 95.15 \\
\hline 90 & 2.86 & 60.10 & -2.26 & 25.90 & 26.04 & 95.01 \\
\hline 120 & 2.86 & 60.01 & -2.21 & 25.83 & 26.11 & 95.17 \\
\hline
\end{tabular}

strength values with increasing time is due to the reason that when we increase contact time of dye and solvent more dye dissolves in water due to hydrolysis ${ }^{10}$. The increase in extraction time from 90 min does not further increase colour strength value (Fig. 3).

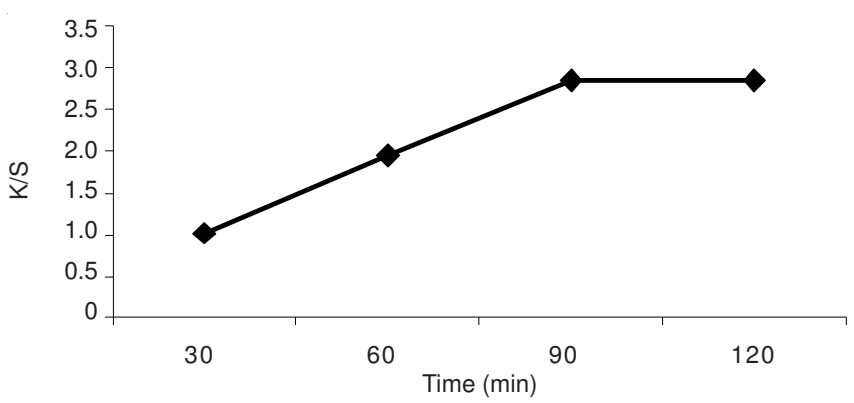

Fig. 3. Effect of extraction time on colour strength

The resulting optimized extracting conditions are given in Table-4.

\begin{tabular}{ccc}
\multicolumn{3}{c}{ TABLE-4 } \\
OPTIMIZED EXTRACTION CONDITIONS \\
\hline Temperature $\left({ }^{\circ} \mathrm{C}\right)$ & Time $(\mathrm{min})$ & M:L Ratio \\
\hline 100 & 90 & $1: 20$ \\
\hline
\end{tabular}

\section{Optimization of dyeing conditions}

Effect of dyeing temperature: It is evident from the Table-5 that the colour strength values increases with increase in temperature. It could be due to fibre swelling and deaggregation of dye at higher temperatures ${ }^{11}$ (Fig. 4).

\begin{tabular}{|c|c|c|c|c|c|c|}
\hline \multicolumn{7}{|c|}{$\begin{array}{c}\text { TABLE-5 } \\
\text { EFFECT OF TEMPERATURE ON COLORIMETRIC } \\
\text { VALUES FOR DYEING CONDITIONS }\end{array}$} \\
\hline Temp. $\left({ }^{\circ} \mathrm{C}\right)$ & $\mathrm{K} / \mathrm{S}$ & $\mathrm{L}^{*}$ & $\mathrm{a}^{*}$ & $b^{*}$ & $\mathrm{c}^{*}$ & $\mathrm{~h}$ \\
\hline 40 & 1.25 & 59.51 & -2.25 & 25.74 & 25.40 & 95.34 \\
\hline 60 & 1.82 & 60.38 & -2.27 & 25.68 & 25.71 & 95.52 \\
\hline 80 & 2.14 & 60.35 & -2.24 & 25.61 & 25.93 & 95.50 \\
\hline 90 & 2.87 & 60.03 & -2.25 & 25.91 & 26.00 & 95.06 \\
\hline
\end{tabular}

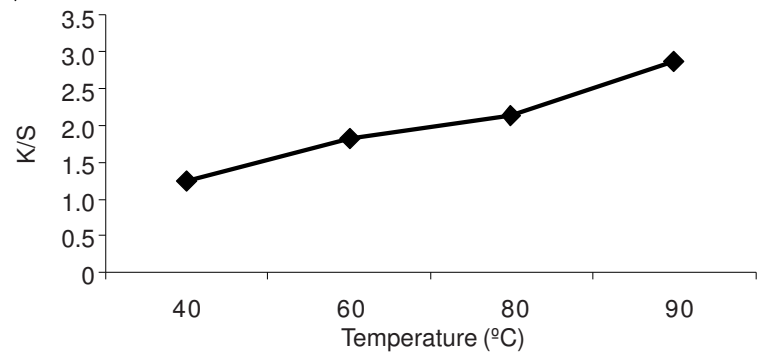

Fig. 4. Effect of dyeing temperature on colour strength

Effect of M:L ratio for dyeing: Colour characteristics of dyed fabric under the effect of liquor ratio presented in Table- 6 shows that, the colour strength values increases with increase in M:L ratio. When we increase the volume of extract with which fabric is to be dyed, means more dye is available for dyeing same weight of fabric. Due to this more dye molecules approached to fabrics, resulting an increase in colour strength value. The $\mathrm{M}$ : $\mathrm{L}$ ratio 1:30 has the even and brighter shade and also has the maximum colour strength. So it is considered optimized (Fig. 5).

\begin{tabular}{ccccccc}
\multicolumn{7}{c}{ TABLE-6 } \\
\multicolumn{7}{c}{$\begin{array}{c}\text { EFFECT OF M:L RATIO ON COLORIMETRIC } \\
\text { VALUES FOR DYEING CONDITIONS }\end{array}$} \\
\hline M:L & K/S & $\mathrm{L}^{*}$ & $\mathrm{a}^{*}$ & $\mathrm{~b}^{*}$ & $\mathrm{c}^{*}$ & $\mathrm{~h}$ \\
\hline $1: 10$ & 1.02 & 58.10 & -2.97 & 24.78 & 24.21 & 94.89 \\
$1: 20$ & 1.72 & 59.32 & -2.52 & 25.75 & 25.96 & 95.05 \\
$1: 30$ & 2.86 & 60.07 & -2.27 & 25.96 & 26.10 & 95.12 \\
\hline
\end{tabular}

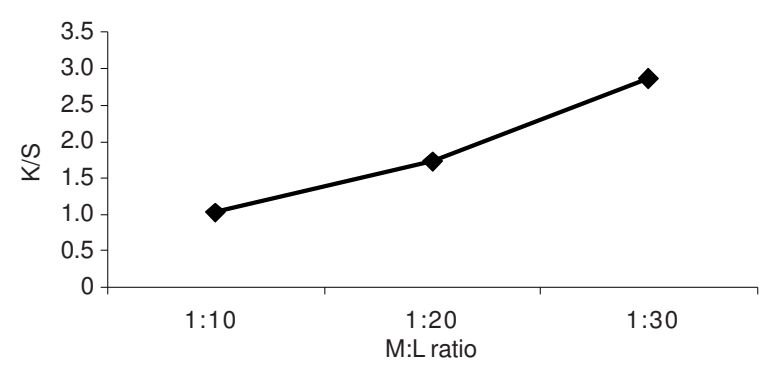

Fig. 5. Effect of M:L ratio on colour strength

Effect of dyeing time: As the time for dyeing increase, colour strength value increases but there is a decrease in colour strength by further increasing dyeing time from $1 \mathrm{~h}$. This could be due to shift in equilibrium of colorant from fabric to dye bath. From the colours strength values given in the Table-7, it is clear that dyeing for $1 \mathrm{~h}$ shows higher colour strength. So dyeing for $1 \mathrm{~h}$ was considered as optimized (Fig. 6).

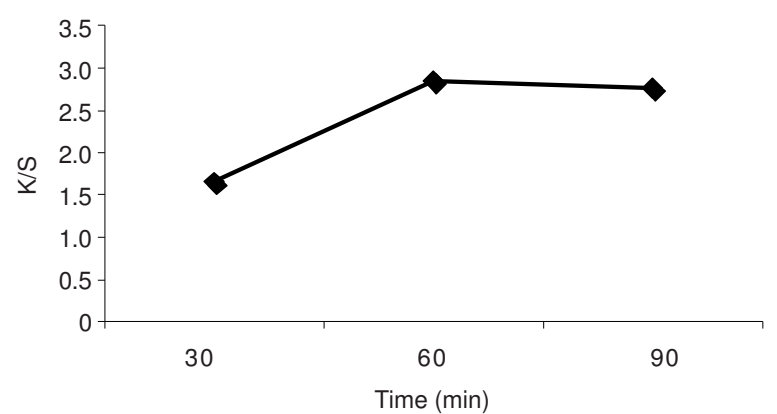

Fig. 6. Effect of dyeing time on colour strength 


\begin{tabular}{ccccccc}
\hline \multicolumn{7}{c}{ TABLE-7 } \\
EFFECT OF DYEING TIME ON COLORIMETRIC \\
VALUES FOR DYEING CONDITIONS \\
\hline Time (min) & K/S & L $^{*}$ & $\mathrm{a}^{*}$ & $\mathrm{~b}^{*}$ & $\mathrm{c}^{*}$ & $\mathrm{~h}$ \\
\hline 30 & 1.65 & 60.13 & -2.25 & 25.40 & 25.35 & 95.20 \\
60 & 2.86 & 60.12 & -2.25 & 25.94 & 26.00 & 95.13 \\
90 & 2.75 & 60.10 & -2.30 & 25.71 & 24.40 & 95.61 \\
\hline
\end{tabular}

Optimization of salt concentration for dyeing conditions: It is evident from the Table- 8 that $\mathrm{K} / \mathrm{S}$ value increases with the increase in salt concentration. It could be due to increase of dye uptake with increase in salt concentration. K/S value and the colour coordinates values were higher of the sample which was dyed with $60 \mathrm{~g} / \mathrm{L}$ of sodium sulphate $\left(\mathrm{Na}_{2} \mathrm{SO}_{4}\right)$. So, it is considered as optimized (Fig. 7).

TABLE-8
\begin{tabular}{ccccccc} 
EFFECT OF SALT CONCENTRATION ON COLORIMETRIC \\
VALUES FOR DYEING CONDITIONS \\
\hline Salt conc. $(\mathrm{g} / \mathrm{L})$ & K/S & $\mathrm{L}^{*}$ & $\mathrm{a}^{*}$ & $\mathrm{~b}^{*}$ & $\mathrm{c}^{*}$ & $\mathrm{~h}$ \\
\hline 20 & 2.26 & 58.14 & -2.97 & 25.14 & 24.90 & 95.25 \\
40 & 2.42 & 59.52 & -2.24 & 25.64 & 25.68 & 95.16 \\
60 & 2.85 & 60.12 & -2.26 & 25.90 & 26.05 & 95.03 \\
\hline
\end{tabular}

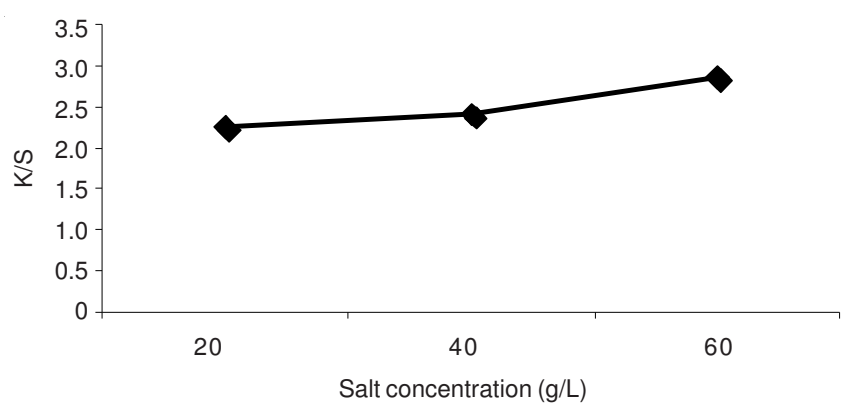

Fig. 7. Effect of salt concentration on colour strength

Effect of premordanting: In pre-mordanting the material is impregnated directly with the mordant (alum) and then dyeing is subsequently done in the separate bath.

The resulting optimized dyeing conditions are summarized in Table-9.

\begin{tabular}{cccc} 
& \multicolumn{3}{c}{ TABLE-9 } \\
& OPTIMIZED DYEING CONDITIONS \\
\hline M:L ratio & Temp. $\left({ }^{\circ} \mathrm{C}\right)$ & Time $($ min $)$ & Salt concentration $(\mathrm{g} / \mathrm{L})$ \\
\hline 1:30 & 90 & 60 & $60\left(\mathrm{Na}_{2} \mathrm{SO}_{4}\right)$ \\
\hline
\end{tabular}

It is inferred from the Table- 10 that at $90{ }^{\circ} \mathrm{C}$ the mordant concentration $(10 \%)$ showed the higher $\mathrm{K} / \mathrm{S}$ value than at $60{ }^{\circ} \mathrm{C}$. At low temperature i.e., $60^{\circ} \mathrm{C}$, the fabric polymers shrink and they do not provide much space for entering the dye molecules into the fabric because the temperature is too low. At higher temperature i.e., $90^{\circ} \mathrm{C}$ the fabric molecules become loosely held and they provide much space for the penetration of dye molecules into the fabric. As a result the colour strength value increases. So $90{ }^{\circ} \mathrm{C}$ at $10 \%$ mordant conc. of alum is optimized temperature (Fig. 8).

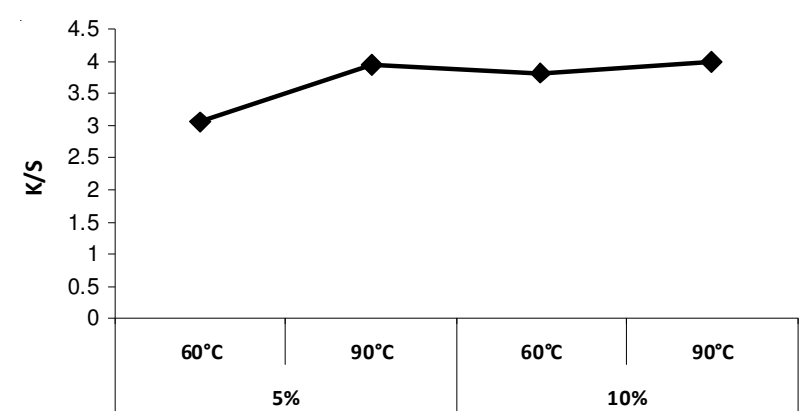

Fig. 8. Effect of pre mordanting conditions on colour strength

Effect of post mordanting: The experiments were performed for post-mordanting with ferrous sulphate $\left(\mathrm{FeSO}_{4}\right)$. It can be observed from the Table-11 that colour strength values increased by increasing the concentration of mordant. The high colour strength value can be attributed to strong bond formation of ferrous sulphate with dye and fabric. Highest $\mathrm{K} / \mathrm{S}$ value was obtained at $90^{\circ} \mathrm{C}$ with $10 \%$ mordant concentration. Teli, et al. ${ }^{12}$ reported that higher colour strength values were achieved by increasing the concentration of mordant (Fig. 9).

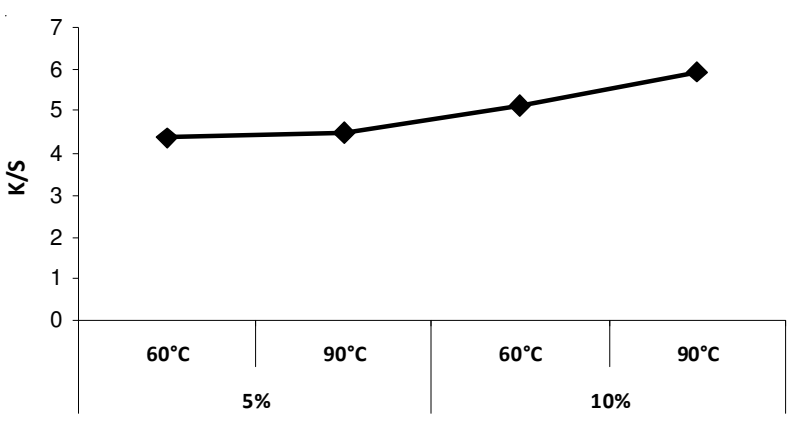

Fig. 9. Effect of post mordanting conditions on colour strength

TABLE-10

EFFECT OF PRE MORDANTING CONDITIONS ON COLORIMETRIC VALUES

\begin{tabular}{|c|c|c|c|c|c|c|c|}
\hline Mordant conc. (\% o.w.f) & Temperature $\left({ }^{\circ} \mathrm{C}\right)$ & $\mathrm{K} / \mathrm{S}$ & $\mathrm{L}^{*}$ & $a^{*}$ & $\mathrm{~b}^{*}$ & $\mathrm{c}^{*}$ & $\mathrm{~h}$ \\
\hline \multirow{2}{*}{5} & 60 & 3.06 & 64.02 & -1.31 & 18.96 & 17.91 & 94.64 \\
\hline & 90 & 3.96 & 64.10 & -1.35 & 18.61 & 17.95 & 94.98 \\
\hline \multirow{2}{*}{10} & 60 & 3.81 & 65.00 & -1.25 & 18.94 & 18.13 & 94.03 \\
\hline & 90 & 3.99 & 65.05 & -1.33 & 18.95 & 18.15 & 94.00 \\
\hline
\end{tabular}

TABLE-11

EFFECT OF POST MORDANTING CONDITIONS ON COLORIMETRIC VALUES

\begin{tabular}{|c|c|c|c|c|c|c|c|}
\hline Mordant conc. (\% o.w.f) & Temperature $\left({ }^{\circ} \mathrm{C}\right)$ & $\mathrm{K} / \mathrm{S}$ & $\mathrm{L}^{*}$ & $a^{*}$ & $\mathrm{~b}^{*}$ & $\mathrm{c}^{*}$ & $\mathrm{~h}$ \\
\hline \multirow{2}{*}{5} & 60 & 4.35 & 43.56 & -4.05 & 29.95 & 28.79 & 96.35 \\
\hline & 90 & 4.48 & 42.32 & -4.96 & 29.96 & 29.21 & 96.68 \\
\hline \multirow{2}{*}{10} & 60 & 5.13 & 42.21 & -4.25 & 29.93 & 29.23 & 96.98 \\
\hline & 90 & 5.94 & 42.00 & -4.18 & 29.71 & 30.11 & 97.00 \\
\hline
\end{tabular}




\begin{tabular}{|c|c|c|c|c|c|c|}
\hline \multicolumn{7}{|c|}{$\begin{array}{c}\text { TABLE-12 } \\
\text { EFFECT OF MORDANTING CONDITIONS ON COLOUR F }\end{array}$} \\
\hline \multirow{2}{*}{ Mordanting } & \multirow{2}{*}{$\begin{array}{l}\text { Mordant conc. } \\
\text { (\% o.w.f })\end{array}$} & \multirow{2}{*}{ Temperature $\left({ }^{\circ} \mathrm{C}\right)$} & \multirow{2}{*}{ Wash fastness } & \multirow{2}{*}{ Light fastness } & \multicolumn{2}{|c|}{ Rubbing fastness } \\
\hline & & & & & Dry & Wet \\
\hline \multirow{4}{*}{ Pre mordanting } & \multirow{2}{*}{5} & 60 & 3 & 4 & $3-4$ & 3 \\
\hline & & 90 & 3 & 5 & $3-4$ & 3 \\
\hline & \multirow{2}{*}{10} & 60 & $3-4$ & 5 & $3-4$ & 3 \\
\hline & & 90 & 4 & 5 & 4 & $3-4$ \\
\hline \multirow{4}{*}{ Post mordanting } & \multirow{2}{*}{5} & 60 & $3-4$ & 5 & $3-4$ & 3 \\
\hline & & 90 & 4 & $5-6$ & 4 & 3 \\
\hline & \multirow{2}{*}{10} & 60 & 4 & 5 & 4 & $3-4$ \\
\hline & & 90 & 4 & $5-6$ & $4-5$ & $3-4$ \\
\hline
\end{tabular}

Colour fastness properties: The results of colour fastness properties presented in Table-12 shows that ratings for post mordanting is better than pre mordanting. This could be due to better formation of coordination complexes by ferrous sulphate between dye and fibre. Furthermore rating is improved by increasing temperature and concentration of mordant.

\section{Conclusion}

Optimization of dyeing conditions is must to minimize the investment cost and to avoid discrepancy in the dyed fabric quality. The study reveals that extraction and dyeing parameters have significant effect on colour characteristics and quality of cotton fabric. The optimized extraction conditions were; $\mathrm{M}: \mathrm{L}$ ratio 1:20, extraction time $90 \mathrm{~min}$ and temperature $100{ }^{\circ} \mathrm{C}$ while the most suitable optimized dyeing parameters were; M:L ratio 1:30, dyeing time $1 \mathrm{~h}$, temperature $90^{\circ} \mathrm{C}$ and salt concentration $60 \mathrm{~g} / \mathrm{L}$ of $\mathrm{Na}_{2} \mathrm{SO}_{4}$. Better fastness properties were obtained in case of post mordanting with ferrous sulphate as compared to pre mordanting with alum.

\section{REFERENCES}

1. Y.H. Lee, E.K. Hwang, Y.J. Jung, S.K. Do and H.D. Kim, J. Appl. Polym. Sci., 115, 2246 (2010).

2. C.L. Green, Natural Colorants and Dyestuffs, Food and Agriculture Organization of the United Nations, Italy (1995).

3. D.J. Styer and R.D. Durbin, Horticult. Sci., 16, 768 (1981).

4. Z.M. Win and M.M. Swe, In Proceedings of International Conference on Agricultural, Biotechnology, Biological and Biosystems Engineering: Purification of the Natural Dyestuff Extracted from Mango Bark for the Application on Protein Fibres, World Academy of Science, Engineering and Technology, pp. 536-540 (2008).

5. E.R. Trotman, Dyeing and Chemical Technology of Textile Fibres, Chares Griffin \& Company Ltd., London, edn. 6 (1984).

6. T.L. Bosma, J.M. Dole and N.O. Maness, Crop Sci., 43, 2118 (2003).

7. B.G. Heo, H.J. Jang, S.H. Kim, H.Y. Kim, Y.K. Yoo, J.Y. Cho and Y.J. Park, Korean J. Horticult. Sci. Technol., 3, 22 (2004).

8. S. Pant, Textile Dyer Printer, 31, 11 (1998).

9. J. Verghese, Ind. Sp., 33, 8 (1998).

10. F.A. Nagia and R.S.R. El-Mohamedy, Dyes Pigments, 75, 550 (2006).

11. V.A. Shenai, Technology of Textile Processing, Sevaic Publications, India, Vol. 2, p. 159 (1997).

12. M.D. Teli, A.N. Nayak, V.B. Nawathe and R.V. Adivrekar, J. Tex. Assoc., 54, 297 (1994). 